The International Journal of Engineering and Science (IJES)

|| Volume || 6 || Issue || 4 || Pages || PP 14-20 || 2017 ||

ISSN (e): $2319-1813$ ISSN (p): $2319-1805$

tertives

\title{
The History and Development of Aviation in the State of Kuwait
}

\author{
Fadala Hassan Alfadala \\ Higher Institute of Telecommunication and Navigation State of Kuwait
}

\section{INTRODUCTION}

The aviation industry today is a growing industry but is faced with many challenges that entail "rough decisions, forcing them to ground planes, pare fleets, consolidate routes, and cut staff" ("2011 Global Aerospace Outlook," 2011). As a result, airline companies try to survive by having leaner organizations that aspire for efficiency; they aim for competitiveness and yet work on reducing costs in all possible ways. They are bombarded with issues such as increasing or fluctuating fuel prices which affect their profit margins; there are also companies that approach challenges with a "wait and see" attitude as they await what will happen and how they will perform as situations happen; but there also those that are confronted by emerging developments that challenge them to increase their fleets, number of routes and seat capacities; they are also pressed with the need to find other lucrative businesses to augment future profitability like charging fees for checked bags, food or in-flight entertainment; they may also offer operating leases as fleet financing opportunity for many airlines.

Being part of the aviation industry also requires aviation companies to keep abreast of what is new in the global aviation market. Although it is a promising market having steady growth and development, there is a growing need to continually upgrade or innovate to make the industry lucrative in a global scale.

Kuwait aviation industry may appear to be in an aggressive position as it pioneered its regional aviation market in becoming one of the biggest beneficiaries of the regions expansive growth that can attract more than 237 million travelers in a year. Kuwait is being developed to offer standard global aviation show in the region.

\section{Part 1: The History and Development of Aviation in Kuwait History}

The Kuwait Aviation's early development can be traced back in 1927-1928, when Kuwait opened its first airport located in the Dasma area, which is a bit far from the city. It was called the Dasma Airport and the Imperial Airways was the airlines that sent the first flights to Kuwait. Imperial Airways was related to British Airways because Kuwait was once a British protectorate and so Britain was supporting the development of Kuwait in the early $19^{\text {th }}$ century until Kuwait was recognized as an independent emirate.

Kuwait airport was used as the desert landing strip for refueling on Britain-India-Britain air route and later on, it conducted its first regular civil aircraft operations. When the discovery of oil came about, Kuwait's aviation became more progressive as it developed new airport that catered to increasing air traffic however, this was put on hold in 1939 because of the outbreak of the Second World War. After the said World War in 1947, Kuwait developed a new airport, Al-Nugra, which was located in Nuzha district. It was only operating during the day to serve the Arab expatriate community. It grew bigger as an airport as developments were rapidly happening to serve increasing market.

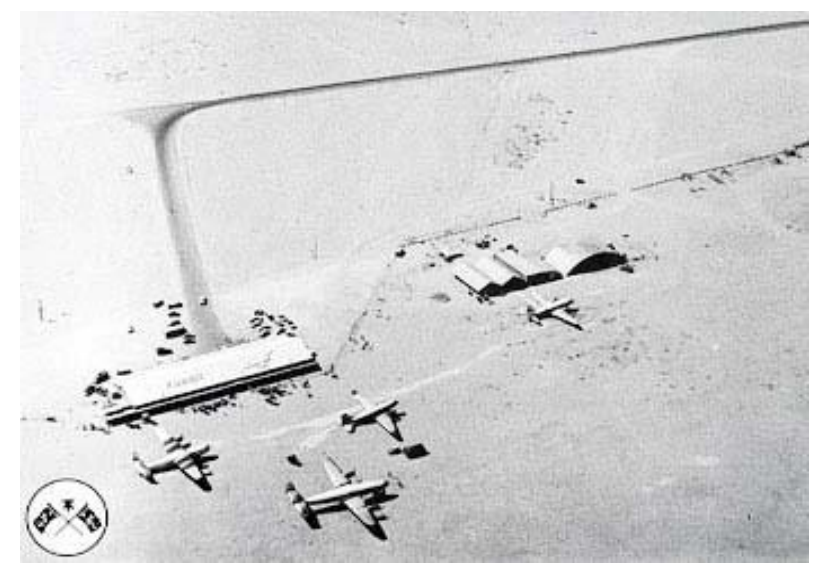

Fig.1 Kuwait airport in 1947 


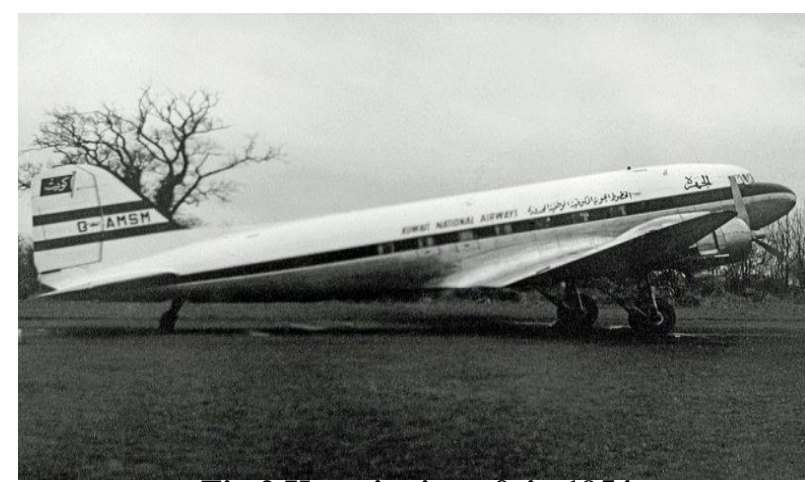

Fig.2 Kuwait aircraft in 1954

In 1954, Kuwait came up with a national carrier, Kuwait National Airways Company Limited. Pilots were trained and given recognition by both Kuwait and Britain. In 1955, the name was changed to Kuwait Airways Corporation and it grew bigger as a company when the government of Kuwait put in more investments into the company. In 1956, the government established its Kuwait Civil Aviation Department, where Kuwait Airport reported to. The said Civil Aviation Department was responsible for formulating Objectives and drafting Aviation Affairs Policy (History, 2017).

In 1960, the State of Kuwait became signatory to the International Civil Aviation Chicago Agreement. This made Kuwait aviation grew further as it also established its private airline, Trans Arabia Airways. Law No. 30 was also formulated to organize its Civil Air Navigation, and Law No. 37 put up the Organizing Aircraft Accidents Investigation. This was also the same period when the State of Kuwait earned its independence from Britain, and its aviation development put forth increasing developments like putting up of Mugwa Airport, which catered to welcoming various airlines like BOAC, Lufthansa, KLM, United Arab Airlines, Saudi Arab Airlines, Syrian Arab Airlines, Air India and Lebanese carriers. The Mugwa Airport comprised passenger terminal with a 2,200 - metre asphalt runway, parking apron, control tower that oversaw round-the-clock operations (History, 2017).

As the Kuwait Government saw the need to further develop its aviation, it acquired full ownership over Kuwait Airways Corporation. It even declared the Amiri Decree creating the Civil Aviation sector which earned for itself its full membership with the International Civil Aviation Organization and World Meteorology Organization in 1963. It also set aside budget to financially support its administration. In 1964, it acquired Trans Arabia Airways and transferred its four DC-6s to Kuwait Airways. The Mugwa Airport expanded its runways and built new control tower.

Moreover, in 1975, the Civil Aviation Department was renamed as Directorate General of Civil Aviation (DGCA) and is headed by a Director General, whose rank in the government is equivalent to Undersecretary. Through DGCA, the Kuwait Government continued to enhance its airlines and passengers facilities at Mugwa Airport to welcome further growth and development. Millions of passengers come and go within a 24-hour operation. Communication lines have also improved and the use of technology has also increased its sophistications that cater to the increasing demand for sophisticated technology that support the aviation industry as well as the tourism industry.

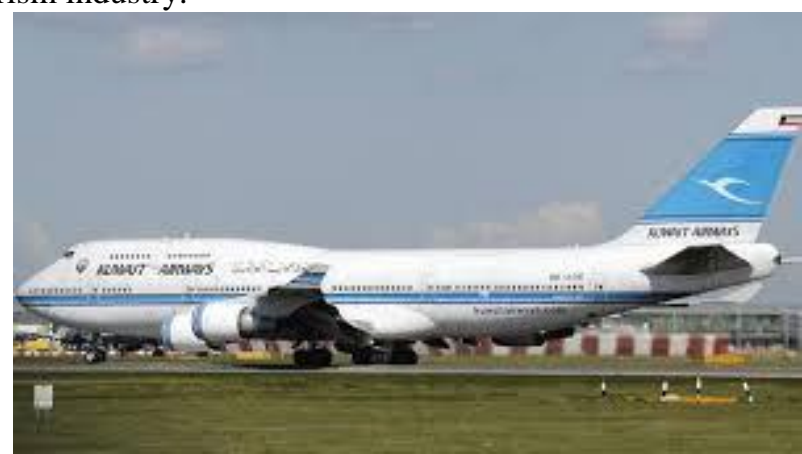

Fig.3 Kuwait airways in 1975 


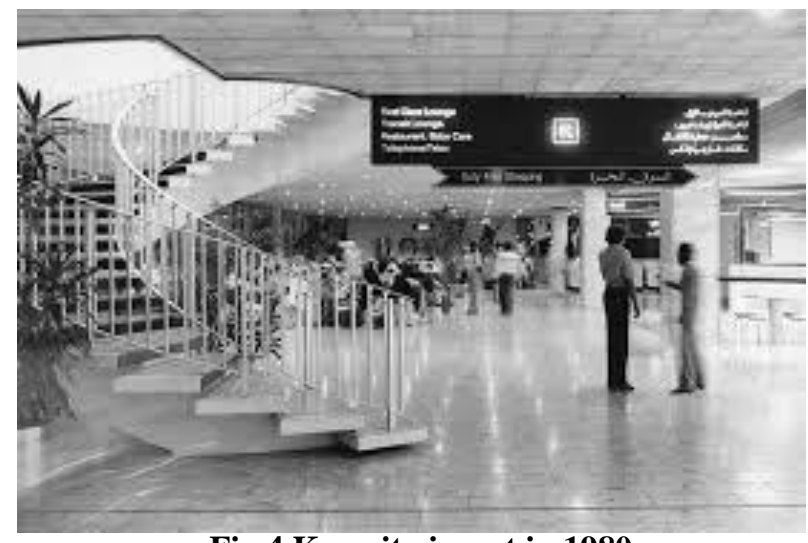

Fig.4 Kuwait airport in 1980

Sometime in 1990 Iraqi invaded Kuwait which damaged airport's infrastructure costing around 100 million KD. Kuwait was saved by coalition forces which freed Kuwait from Iraqi's invasion. Kuwait Aviation resumed its operations but with limited services to give way to restore its airport infrastructure to full operation in December 1991. In 1996, a number of laws were issued to restructure the DGCA and new departments and offices were created to cover the essential areas of aviation operations. The Kuwait Aviation continually improved its airspace system by rolling out a number of innovations in monitoring and controlling the systems. It also expanded its Duty Free complex to give more room for commercial centers to be opened to cater to increasing market; it also embarked on various developments in increasing capacity to operate bigger scope of aviation services such as but not limited to the following: completing the Supervisory Control and Data Acquisition installation for KIA's $11 \mathrm{KV}$ power distribution system; Doppler Weather Radar and Low Level Wind Shear alert system; more commercial concessions were installed to facilitate ground handling services; offering of low-cost carrier such as Jazeera Airways was initiated to facilitate passengers that go for cheaper airplane rates to fly them over to Dubai and Beirut. DGCA also opened its skies to allow other airlines to utilize Kuwait's increasing business and leisure traffic. As a result, Kuwait is able to develop increasing market for tourism industry to flourish. More tourism centers have been developed to welcome over 6 million passengers and are continually increasing, to visit Kuwait annually hence the need to restructure the DGCA to create posts that could effectively serve the increasing demands for quality services of Kuwait's aviation industry. Among the important areas identified are the Administrative Affairs and Information Systems, Kuwait International Airport Affairs, Air Navigation, Aviation Safety \& Air Transport Affairs, Financial and Legal Affairs (History, 2017).

\section{DEVELOPMENT}

Kuwait aviation is rising steadily and its government sees the need to continually invest its capital on its growth and development. As increasing volume of international passengers are coming in, Kuwait is enjoying heightened regional activity for tourism industry. More passengers are looking for low-cost carriers (LCCs) and Kuwait government sees it as an opportunity to meet the new demand. With the more improved airport facilities and services, it ventures on renewing efforts to privatize the national carriers to cater to this increasing market demand. Kuwait Airways for one is paving the way to meet the growing demand for airlines today and the years ahead.

In 2012, the Kuwait International Airport made a record of 8.9 million passengers compared to the 2008 record of 7.23 million. This apparently tells that the airport is doing well in meeting its target number of passengers annually and potentially hitting its goal to reaching 13 million in 2016. The efforts are clearly set to achieve the goals but there are also identified restraints that could affect the ability to reach KIA's target, such as the following: there are passengers that utilize diverted route considering that KIA's capacity could only accommodate around 2 million travelers; these alternate route are usually reserved for private aircrafts; there is also a need to overhaul the airport so that it could accommodate more travelers and to further boost its growth and development; overhauling requires the need to construct new terminals and expand its runways; it also requires enhanced control tower operations and this means increasing its cargo facilities, and investing on more high-technologies. Furthermore, there is also the move to increase the low-cost carriers so they can address the problem on increasing capacity to transfer passengers from one point of destination to another.

The Kuwait government aims to energize its national economy by opening itself up to investments that are aligned with the Kuwait Development Plan or KDP, which runs from 2015 to 2020. Its strategic goal is to direct 
major investments on key areas like transport and logistics infrastructure and services. This means that Kuwait has to strengthen its sea and air links so as to enhance its capacity to connect with the region and even beyond the scope of the region hence major projects are geared towards improving transportation facilities and services including aviation industry.

As the Kuwait government promotes its fullest potentials to boost its national economy, Kuwait has gained natural advantages to begin with. Its location is an advantage being proximate to populous markets. Its transportation and logistics sector plays a vital role in serving these markets. This calls for more investors in transport and logistics infrastructure and the private sector has a very important role to play in this growing market with the following segments: bus, including the airlines.

Kuwait's aviation sector may be considered in the early stages at this point as compared with its neighboring emirates and in the Middle East. The expansion of investments coming into Kuwait has been moving gradually even if there has already been an approval to have a mega-project to upgrade the airport in 2014 to meet the growing demand of time.

\section{Part 2: The Development of the Fleet of Kuwait Airways}

There have been delays in releasing expansion plan for aviation industry in 2011. This was contributory in its delay to meet the increasing demand for terminals to accommodate travelers. Expanding airports require also room to grow the moment there would be increasing travelers by the millions. Even if there has been allocated budgets to expand airport capacity, there seems to be lack of political will and cooperation to pursue aggressive plans and act upon some necessary reforms. Kuwait is also losing the potentials of capturing the market because of its inability to handle or manage the oversupply of passengers or travelers. The government sees the need to ask help from the private sector in managing commercial ports and the international airport. Kuwait Airways, through legislation, is opened for privatization to instill productivity. Because of its congested airlanes, proper legislations have to be passed to become laws and help utilize aviation revenues to boost the economy (Trenwith, 2016).

Increasing capacity to facilitate increasing travelers can be addressed if there are more low-cost carriers. Kuwait-based LCC, Jazeera Airways, is on its way to address this problem and just recently, Kuwait government has granted it to build its own terminal and facilities at the Kuwait International Airport. With Jazeera Airways, its impressive performance results to increasing profits in 2012 with a $32 \%$ increase compared to its 2009 performance. It also sees a promising future for the aviation industry and is banking on a healthier business by increasing its Kuwait aviation business alone ("Kuwait sets...," 2013).

The LCCs are expanding its market hence the privatization of national carrier, Kuwait Airways Company, aims to make it more attractive for strategic investors to invest in it. The move towards privatization is also geared towards serving the aviation industry in the GCC by freeing the region for free and fair competition and boosting its economy as a region ("Kuwait sets...," 2013). Take for instance, Turkey's Limak Holding and local construction firm Kharafi National won a bid to build a new terminal that can cater to double capacity for a cost of $\$ 4.34$ billion (Trenwith, 2016). The construction has been prompted by the need for Kuwait to catch up with the time as it deals with lost opportunities if it does not address the demand for more capacity to facilitate travelers. With the new passenger terminal, it can accommodate to handle 25 million passengers in a year; it can also handle all types of aircraft standing in 51 new gates (Fahy, 2016). What is foreseen in building the new airport is to become an effective link between two countries- Kuwait and Turkey; using this link, supported by the use of new technologies, it will create new projects, new jobs for the people locally; it also opens doors for local businesses to flourish, while allow more opportunities for Kuwait people to use their education and knowledge while being empowered to executive initiatives and plans for Kuwait.

The move for enhancing, upgrading Kuwait International Airport is also aligned with the move of the other Arabian Gulf's governments to invest in developing their airports amidst various challenges in their areas like lowering of oil prices that constrain their budgets. To mention a few are Dubai, for expanding its Al Maktoum International terminal by increasing its capacity to accommodate passengers from 5 million to 26.5 million; Saudi Arabia, for granting an operate and maintain concession for Riyadh Airport; and Abu Dhabi, for running retail operations at its Abu Dhabi International's new Midfield Terminal Building (Fahy, 2017).

On Kuwait Airways

Kuwait Airways, being a national carrier, used to be called Kuwait National Airways Company in 1954, had an initial 25\% government stake. It was renamed as Kuwait Airways Corporation when the government doubled its holding in the company in 1955. It embarked on redeveloping its operations in 1990-1991 as a result of the Gulf War. The redevelopment brought forth increase in ticket sales and revenues, which grew year after year. Kuwait Airways continues to embark on more ambitious targets; it has continually upgraded its fleet; it purchased new aircrafts and catered to its regional market; it expanded its flights by having long-haul routes like reaching far destinations like New York and Los Angeles; for more developments, it had to engage in highly coveted airport slots like London Heathrow, where the biggest markets are, just to capture greater bulk of the market. 


\section{Kuwait Airways’ Directions}

Kuwait Airways is one of the most admired airlines to fly, to invest in, and to work for because it focuses its efforts and directions towards providing customer-oriented services that meet every passengers' needs ("About us," 2017). Premium products are offered so it can serve value for money service to clients; it aims further to be globally accessible and yet offers a local touch when it comes to its service. It commits to provides continually enhanced services. Its services is primarily geared towards serving the Kuwait community and hopes to be the preferred carriers for its people for inbound business travels; it also aims to link its services of providing both business and leisure across regions. It cannot just promise to provide customer-oriented services and premium products but is also committed to become financially viable in order to grow in line with the market demand in Kuwait. It continues to become an attractive investment for private sector so that the latter can see the benefit of investing in it. It also has to stay profitable as an enterprise so that it is able to sustain future directions of becoming a valued and preferred airline in Kuwait and its other areas of influence.

On Privatization of Kuwait Airways

Kuwait Airways has no way but to move in parallel with government to privatize its ownership for some reasons: (1) Kuwait Airways is a government-owned airline and it is huge company that employs a number of people. Since it employs a number of people, it has to protect the interests of its employees and by doing so would mean protecting their rights to enjoy reforms in the company. Even if the Kuwait government has retained its stake by $20 \%$, the remaining portion is distributed to the following: $35 \%$ shares go to the private sector investors, while $40 \%$ goes to the citizens of Kuwait; the remaining $5 \%$ goes to employees of the airlines.

On Jazeera Airways

Jazeera Airways operation was a breakthrough considering that Kuwait has seen the need to liberalize the airline industry in 2003 because more people were looking for low-cost carriers and Kuwait Airways could not afford to just let go of this market without serving this market. Jazeera Airways came into the picture being the first fully privatized airlines that operate in the Middle East. It was launched by having an initial public offering in June 2004 at a price of $\$ 34 \mathrm{~m}$. Its first flight was serving Dubai with its new business model. On its initial operations, Jazeera Airways was already utilizing sophisticated technologies that support its new business model; it has a strong call centre and online presence where most of its bookings are coursed through these channels; its operations were geared towards maximizing the utilization of its aircrafts while at the same time trying to reduce its turnaround times. As a result, it gained increasing profitability by transporting passengers and reducing traffic in Kuwait. It has grown as a company being the second -biggest airline in Kuwait, beating competitors like the Emirates, Qatar Airways and Flydubai.

Wataniya Airways was the next airline that was launched in Kuwait. This airline is a premium airline that offers only business and premium economy seats. But because of its high costs and it had to deal with tough competition not only in Kuwait but also globally, Wataniya Airways had to close its operations in 2011 but its operations resumed in 2015 after conducting a fund raising initiative to sustain its operations.

On fleet development

Kuwait Airways has no way but to push through with its fleet development. Being a national airline of the State of Kuwait, has to acknowledge the need to improve its aircrafts as a way to invite more travelers choosing Kuwait Airways over other airlines. Kuwait Airways has to upgrade its aircrafts by utilizing Airbus A320 CEO aircraft; it is now the world's best selling single-aisle aircraft family which is versatile enough to cater to a wider range of services Kuwait Airways is able to offer. It is also responsible for upgrading its Runway Overrun Prevention System (ROPS) technology that increases pilots' situational awareness during landing, reducing exposure to runway excursion risk and providing active protection. Inclusive of the upgrade is also the passengers' privilege to access to other services like accessing to satellite live television broadcasts using their own language; it also enables passengers to view landscape cameras, listen to international news or connecting flight information ("Kuwait Airways," 2015). Moreover, Kuwait Airways also provides more legroom to its passengers and allows them to connect their own Personal Electronic Devices like laptop, tablet, and smartphones. They can also enjoy listening to high quality audio headsets while enjoying the comfort of viewing movies onboard on larger screens. With this airline, passengers enjoy better comfort considering its better flight service.

When interviewed about Kuwait Airways, Abdullah Al-Sharhan, CEO of Kuwait Airways, shared that the company "works on coping with the expansion process through developing and expanding its fleet up to 47 aircraft." (DGCA, 2015). He also added that "next year will witness the replacement of 10 aircraft (Boeing 777) by airplanes of Airbus A340 model and Boeing operating on existing network;" (DGCA, 2015). He further mentioned that "the company has signed a contract for the purchase of 15 A320neo aircraft that will be received in 2019-2021 and then 10 A350-900 aircraft in 2020-2022" (DGCA, 2017). To complement these new developments, efforts are also exerted to Kuwait Airways when terminal II is now being expanded and works will be completed in five years to serve the increasing challenges of airports across the globe. 


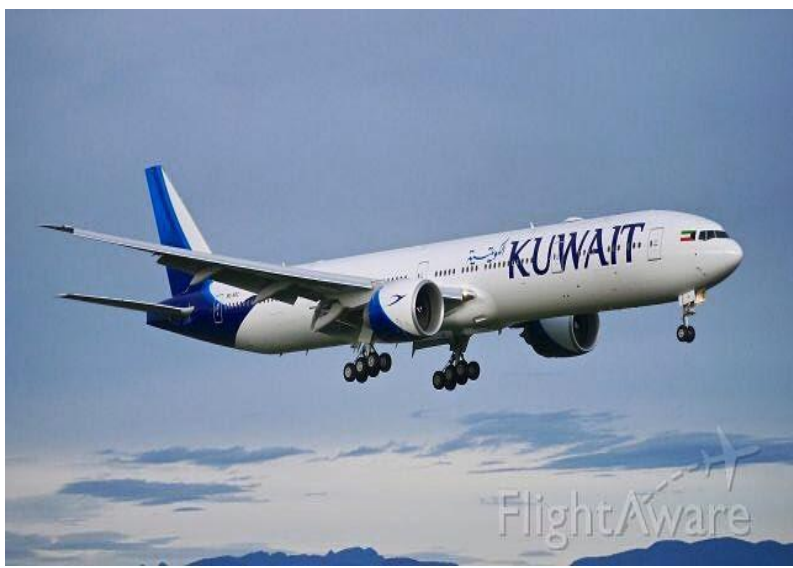

Fig.5 Kuwait airways in 2017

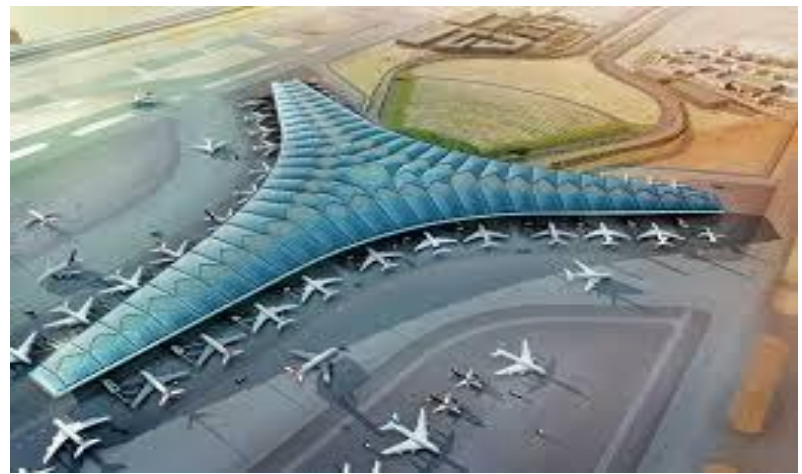

Fig.6 Kuwait airport in 2020

\title{
III. CONCLUSION
}

The Aviation is continually evolving and is subjected to a number of challenges that could threaten the business and its sustainability. To survive in this industry is to keep up with the trend, like evolving technology and changing customer preference, and to continually aspire and work towards growth and development so that in doing so, the company can expand and increase its capacity to serve more passengers globally. The way to cope up with the cost of doing it is to partner with the private sector or open the business up to investors who are willing partners in moving forward while taking risks in order to achieve better returns on investment.

\begin{abstract}
Summary
This paper presents Kuwait's aviation industry and how it is able to face various challenges today. The Kuwait Airways, being the national airline of Kuwait, is also facing challenges that pose the future of its business. There are ways to sustain it; partnering with private sectors who are willing to invest and take risks is a viable way to survive the business; getting the continuous support from the government is also helpful. As a company one also has to be creative, innovative in staying with the business; it has to be open to new developments that are costly but all of these efforts are geared towards keeping up with the trend and serving customers that continually inspire Kuwait Airways and the aviation industry to achieve greater heights for better results towards achieving productivity and profitability.
\end{abstract}

\section{RECOMMENDATION}

"Why traveling on airplanes is better than other ways?"

Traveling by air is a lot better than any other means of transportation when going to places locally or globally. Besides it takes shorter time to travel to places across the globe, it is also a lot more comfortable to travel by air. Airline companies compete with each other to earn customer preference or loyalty but to sustain their business they have to offer better customer services, improved facilities, more available flights with comfortable accommodations with value for money. Meeting customer expectation is a must in the aviation industry; customers want to see significant improvements in their experiences while travelling; they also expect more affordable airfare to allow them to travel often but reality tells that this is far from reality because despite efforts to put up with better quality service, customer dissatisfaction could remain a continuing challenge to address; reducing costs but increasing efficiency is a must, which may be achieved through enhancements in organizational structure, operating model, and work practices. 
"Way of developing Aviation in Kuwait"

Kuwait Aviation Industry must be seen as a challenging business with promising opportunities to grow, become more profitable, and serve millions of passengers around the globe. Since the business is expanding rapidly amidst emerging markets with tough competition, Kuwait Aviation industry must be open for continual development; it must be willing to take risks in expanding its horizon. Those that form part of said industry must be willing to partner with private sectors that contribute to its growth and development. Furthermore, they must learn to endure the ironies of the industry.

\section{REFERENCES}

[1]. 2011 Global aerospace outlook - Challenges of an ever-changing industry. Forbes Insight, 2011, http://images. forbes. com/forbesinsights/StudyPDFs/CIT_Aerospace_2011.pdf. Accessed 22 February 2017.

[2]. About us-Vision and Goals. Kuwait Airways, 2017, https://www.kuwaitairways.com/en/about/corporate-profile. Accessed 22 February 2017.

[3]. DGCA: Development Projects of Kuwait's Aviation estimated at six bln. Kuwait News Agency, 20 October 2015, http://www. kuna.net.kw/ArticlePrintPage.aspx?id=2466648. Accessed 22 February 2017.

[4]. Fahy, Michael. Limak signs $\$ 4.34$ bn deal to build Kuwait International Airport terminal. The National Business, 30 May 2016 , http://www.thenational.ae/business/aviation/limak-signs-434bn-deal-to-build-kuwait-international-airport-terminal. Accessed 22 February 2017.

[5]. History. Directorate General of Civil Aviation, 2017, https://www.dgca.gov.kw/en/civil-aviation/about-us/history. Accessed 22 February 2017.

[6]. Kuwait Airways completes first phase of fleet development. Wijeya Newspapers Ltd, July 13, 2015, http://www. dailymirror. lk/79317/kuwait-airways-completes-first-phase-of-fleet-development. Accessed 22 February 2017.

[7]. Kuwait Aviation Show to take place in January 2017. Arabian Aerospace Online News Service, 14 January 2016, http://www.arabianaerospace.aero/kuwait-aviation-show-to-take-place-in-january-2017.html. Accessed 22 February 2017.

[8]. Kuwait's infrastructure developing in line with national economic strategy. Oxford Business Group, 2017, https://www. oxfordbusinessgroup.com/overview/stronger-networks-developing-infrastructure-line-national-economic-strategy. Accessed 22 February 2017.

[9]. Kuwait sets scene for aviation industry growth. Oxford Business Group, 18 November 2013, http://www. oxfordbusinessgroup. com/news/kuwait-sets-scene-aviation-industry-growth. Accessed 22 February 2017.

[10]. Kuwait. The Columbia Electronic Encyclopedia, $6^{\text {th }}$ ed. 2012, http://www.infoplease.com/encyclopedia/world/kuwait-history.html. Accessed 22 February 2017.

[11]. Trenwith, Courtney. Is this third time lucky for Kuwait's struggling airport?. Oxford Business Group, 4 June 2016, http://www.oxfordbusinessgroup.com/news/kuwait-sets-scene-aviation-industry-growth. Accessed 22 February 2017. 